\begin{tabular}{|l|l|l|l|l|l|l|}
\hline tapraid1/z30-jep/z30-jep/z3000305/z300587d05a & longd & $\mathrm{S}=5$ & $6 / 30 / 05$ & $11: 53$ & Art: & Input-yyy(psf)
\end{tabular}

Journal of Economic Perspectives_Volume 19, Number 3-Summer 2005-Pages 000-000

\title{
Adam Smith, Behavioral Economist
}

\author{
Nava Ashraf, Colin F. Camerer and \\ George Loewenstein
}

I

n The Wealth of Nations, published in 1776, Adam Smith famously argued that economic behavior was motivated by self-interest. But 17 years earlier in 1759, Smith had proposed a theory of human behavior that looks anything but selfinterested. In his first book, The Theory of Moral Sentiments, Smith argued that behavior was determined by the struggle between what Smith termed the "passions" and the "impartial spectator." The passions included drives such as hunger and sex, emotions such as fear and anger, and motivational feeling states such as pain. Smith viewed behavior as under the direct control of the passions, but believed that people could override passion-driven behavior by viewing their own behavior from the perspective of an outsider - the impartial spectator — a "moral hector who, looking over the shoulder of the economic man, scrutinizes every move he makes" (Grampp, 1948, p. 317). ${ }^{1}$

\footnotetext{
${ }^{1}$ A long-standing dispute has raged over whether Adam Smith's view of human motivation as expressed in The Theory of Moral Sentiments complements or contradicts the view of human motivation expressed in The Wealth of Nations. Although much has been written about "das Adam Smith problem" of reconciling these texts, most modern Smith scholarship asserts that there is no essential contradiction between the texts. As the editors of the Glasgow Edition of the Works and Correspondence of Adam Smith edition of The Theory of Moral Sentiments write, "the so called 'Adam Smith problem' was a pseudo-problem based on ignorance and misunderstanding. Anybody who reads The Theory of Moral Sentiments, first in one of the earlier editions and then in edition six, will not have the slightest inclination to be puzzled that the same man wrote this book and The Wealth of Nations, nor to suppose that he underwent any radical change of view about human conduct."
}

- Nava Ashraf is Assistant Professor in the Negotiation, Organizations and Markets Group at Harvard Business School, Cambridge, Massachusetts. Colin Camerer is Rea A. and Lela G. Axline Professor of Business Economics, California Institute of Technology, Pasadena, California. George Loewenstein is Professor of Economics and Psychology, Department of Social and Decision Sciences, Carnegie-Mellon University, Pittsburgh, Pennsylvania. Their e-mail addresses are

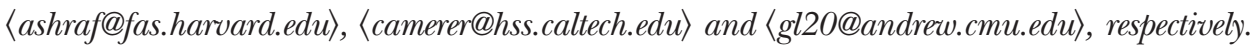




\begin{tabular}{|l|l|l|l|l|l|l|}
\hline tapraid1/z30-jep/z30-jep/z3000305/z300587d05a & longd & $\mathrm{S}=5$ & $6 / 30 / 05$ & $11: 53$ & Art: & Input-yyy(psf) \\
\hline
\end{tabular}

\section{Journal of Economic Perspectives}

The "impartial spectator" plays many roles in The Theory of Moral Sentiments. When it comes to choices that involve short-term gratification but long-term costs, the impartial spectator serves as the source of "self-denial, of self-government, of that command of the passions which subjects all the movements of our nature to what our own dignity and honour, and the propriety of our own conduct, require" (Smith, 1759 [1981], I, i, v, 26), much like a farsighted "planner" entering into conflict with short-sighted "doers" (Shefrin and Thaler, 1981). In social situations, the impartial spectator plays the role of a conscience, dispassionately weighing the conflicting needs of different persons. Smith (I, i, v, 29) recognized, however, that the impartial spectator could be led astray or rendered impotent by sufficiently intense passions: "There are some situations which bear so hard upon human nature that the greatest degree of self-government... is not able to stifle, altogether, the voice of human weakness, or reduce the violence of the passions to that pitch of moderation, in which the impartial spectator can entirely enter into them."

Adam Smith's psychological perspective in The Theory of Moral Sentiments is remarkably similar to "dual-process" frameworks advanced by psychologists (for example, Kirkpatrick and Epstein, 1992; Sloman, 1996; Metcalfe and Mischel, 1999), neuroscientists (Damasio, 1994; LeDoux, 1996; Panksepp, 1998) and more recently by behavioral economists, based on behavioral data and detailed observations of brain functioning (Bernheim and Rangel, 2004; Benhabib and Bisin, 2004; Fudenberg and Levine, 2004; Loewenstein and O'Donoghue, 2004). It also anticipates a wide range of insights regarding phenomena such as loss aversion, willpower and fairness (V. Smith, 1998) that have been the focus of modern behavioral economics (see Camerer and Loewenstein, 2004, for a recent review). The purpose of this essay is to draw attention to some of these connections. Indeed, as we propose at the end of the paper, The Theory of Moral Sentiments suggests promising directions for economic research that have not yet been exploited.

\section{Preferences and the Dual-Process Perspective}

The Theory of Moral Sentiments is packed with insights about preferences, using the dual-process framework of the passions and the impartial spectator. Some of the discussion relates to aspects of individual preference and judgment: what we would today call loss aversion, intertemporal choice and overconfidence. Other parts of the discussion focus on preferences that arise in social contexts: altruism, fairness and how they together generate trust in markets.

\section{Loss Aversion}

Approximately 200 years before Kahneman and Tversky (1979) identified the regularity in choices that has come to be known as "loss aversion," Adam Smith (1759, III, ii, 176-177) displayed an acute awareness of loss-aversion as an experiential phenomenon: "Pain . . . is, in almost all cases, a more pungent sensation than the opposite and correspondent pleasure. The one almost always depresses us much more below the ordinary, or what may be called the natural state of our 


\begin{tabular}{|l|l|l|l|l|l|l|}
\hline tapraid1/z30-jep/z30-jep/z3000305/z300587d05a & longd & $\mathrm{S}=5$ & $6 / 30 / 05$ & $11: 53$ & Art: & Input-yyy(psf) \\
\hline
\end{tabular}

happiness, than the other ever raises us above it." Smith also drew attention to what behavioral economists would now refer to as the underweighting of opportunity costs relative to out-of-pocket costs. Smith (II, ii, ii, 121) notes that "breach of property, therefore, theft and robbery, which take from us what we are possessed of, are greater crimes than breach of contract, which only disappoints us of what we expected." 2

Modern research has not only produced a wealth of evidence supporting both of these effects, but brain imaging technology has shown that that losses and gains are processed in different regions of the brain (O'Doherty, Kringelback, Rolls, Hornak and Andrews, 2001), suggesting that gains and losses may be processed in qualitatively different ways. Moreover, a body of literature has shown that when loss aversion is combined with narrow bracketing of decisions-the tendency to take decisions one at a time without considering the big picture-its effects are evident in asset returns (Benartzi and Thaler, 1997), labor supply (Camerer, Babcock, Loewenstein and Thaler, 1997), the reluctance to sell losing stocks and houses (Odean, 1998; Genesove and Mayer, 2001) and large gaps between buying and selling prices (Kahneman, Knetsch and Thaler, 1990).

\section{Intertemporal Choice and Self-Control}

Intertemporal choice offers a straightforward application of Smith's dual process model. Smith (1759, IV, ii, 273) viewed the passions as largely myopic: "The pleasure which we are to enjoy ten years hence, interests us so little in comparison with that which we may enjoy to-day, the passion which the first excites, is naturally so weak in comparison with that violent emotion which the second is apt to give occasion to, that the one could never be any balance to the other, unless it was supported by the sense of propriety." "The spectator," in contrast, "does not feel the solicitations of our present appetites. To him the pleasure which we are to enjoy a week hence, or a year hence, is just as interesting as that which we are to enjoy this moment" (IV, ii, 272).

The struggle between the myopic passions and farsighted impartial spectator appears later in behavioral economics in the form of a "doer" and "planner" in Shefrin and Thaler (1981; see also Benabou and Pyciak, 2002; Bernheim and Rangel, 2002). What are now called "quasi-hyperbolic discounting models" (Laibson, 1997), in a similar spirit, have also been used by Angeletos, Laibson, Tobacman, Repetto and Weinberg (2001) to study life cycle saving, by O'Donoghue and Rabin (1999) to study life cycle temptation and by Ashraf, Karlan and Yin (2004) to study demand for committed savings in the Philippines. ${ }^{3}$ Moreover, recent research

\footnotetext{
${ }^{2}$ Thaler (1980), who first drew attention to the underweighting of opportunity costs relative to out-of-pocket costs, attributes it to loss aversion; opportunity costs are treated as foregone gains, rather than as losses.

${ }^{3}$ Using the terms of Laibson (1997), these are sometimes called $\beta-\delta$ discounting models. Mapped roughly onto Smith's terms, $\beta$ is the weight on all future outcomes, so that $1 / \beta$ represents the relative strength of the passions that prefer immediate rewards, and $\delta$ is a conventional discount rate. Smith's passage above suggests that the impartial spectator uses $\delta=1$.
} 


\begin{tabular}{|l|l|l|l|l|l|l|}
\hline tapraid1/z30-jep/z30-jep/z3000305/z300587d05a & longd & S=5 & 6/30/05 & 11:53 & Art: & Input-yyy(psf) \\
\hline
\end{tabular}

\section{Journal of Economic Perspectives}

in which decision-makers' brains were scanned while they made intertemporal choices vindicates Smith's view that decisions that provide the potential for pleasures which we may enjoy today activate emotional regions of the brain in a way that decisions involving only delayed outcomes do not (McClure, Laibson, Loewenstein and Cohen, 2004).

\section{Overconfidence}

Adam Smith $(1776, I, x, 1)$ wrote about the "over-weening conceit which the greater part of men have of their own abilities," a pattern of judgment that influences preferences over risky choices. According to Smith, "the chance of gain is by every man more or less over-valued, and the chance of loss is by most men under-valued, and by scarce any man, who is in tolerable health and spirits, valued more than it is worth."

Smith's "overweening conceit" reappears in modern behavioral economics in the form of executive "hubris" that motivates the failure of so many mergers (Roll, 1986) and other business failures (Camerer and Lovallo, 1999) and can be derived theoretically from evolutionary considerations (Waldman, 1993; Compte and Postelwaite, 2005). Moreover, Smith's caveat that overconfidence only applies to those in "tolerable health and spirits" anticipates modern studies showing that people who are not in tolerable health and spirits—specifically, the clinically depressedare the exceptional ones among us who are not optimistic wishful thinkers (for example, Taylor and Brown, 1994).

\section{Altruism}

Judging from the extensive treatment that Adam Smith gave to sympathy in The Moral Sentiments, he viewed it as one of the more important passions. However, he also viewed sympathy as an extremely unreliable guide to moral behavior, sometimes falling short and sometimes exceeding what is morally required.

Smith argued that natural sympathy often falls short of what is morally justified by mass misery. In one evocative passage he noted the striking lack of sympathy that a resident of Europe would be likely to have of an earthquake that eliminated the population of China. After expressing "very strongly his sorrow for the misfortune of that unhappy people," Smith (1759, III, iii, 192-193) commented, such an individual would likely "pursue his business or his pleasure, take his repose or his diversion, with the same ease and tranquility as if no such accident had happened .... If he was to lose his little finger to morrow, he would not sleep to-night; but, provided he never saw them, he will snore with the most profound security over the ruin of a hundred millions of his brethren." Although modern media may help to bring vivid images of distant tragedies into people's homes (like the 2004 Indian Ocean tsunami), thus reducing social distance, such imagery does so in a highly selective fashion that only amplifies Smith's concerns. Recent incidents caught on videotape capture the public's sympathies, but more serious problems that society may have adapted to, or that don't lend themselves to vivid imagery, are as likely as they were in Smith's time to elicit a paucity of sympathy. 


\begin{tabular}{|l|l|l|l|l|l|l|}
\hline tapraid1/z30-jep/z30-jep/z3000305/z300587d05a & longd & $\mathrm{S}=5$ & $6 / 30 / 05$ & $11: 53$ & Art: & Input-yyy(psf) \\
\hline
\end{tabular}

In other cases, Smith believed that people experience sympathy that is completely out of proportion to the plight of the individual one feels sympathetic toward. "We sometimes feel for another, a passion of which he himself seems to be altogether incapable," Smith (1759, I, i, $i, 7-8)$ wrote. "What are the pangs of a mother, when she hears the moanings of her infant, that, during the agony of disease, cannot express what it feels? In her idea of what it suffers, she joins, to its real helplessness, her own consciousness of that helplessness, and her own terrors for the unknown consequences of its disorder; and out of all these, forms, for her own sorrow, the most complete image of misery and distress. The infant, however, feels only the uneasiness of the present instant, which can never be great." Smith adds dryly that "we sympathize even with the dead," who themselves experience nothing.

If humans were under the control of their passions, one could expect to observe extreme callousness alternating with remarkable generosity, with little logic or consistency governing the transitions. This tendency is manifested in the "identifiable victim effect," in which people sympathize more with a known victim than with a statistical likelihood that a not-yet-known person who is likely to be victimized (Schelling, 1984; Small and Loewenstein, 2003). In the political economy, fluctuations in sympathy probably influence public policies, creating huge inconsistencies in the implicit value that different policies place on saving a human life (Tengs and Graham, 1996).

Controlled economics experiments show some fluctuations in expressed sympathy, too. For example, in "dictator game" experiments, people simply divide a known sum of money between themselves and another person. Absent any knowledge about the target recipient, people offer an average of 20 percent (offers of nothing and half are most common; Camerer, 2003, chapter 2). When dictators know the recipient is the Red Cross, rather than a fellow student, the average allocation doubles (Eckel and Grossman, 1996). When the recipient stands up and gives a few facts about him- or herself, the average amount given goes up to half and the variance increases-as if dictator givers generally sympathize when they know a little about somebody, but also make snap character judgments of who is deserving and who is not (Bohnet and Frey, 1999).

These fluctuations in sympathy are moderated, according to Smith, by the impartial spectator. Returning to the case of devastation in China, Smith (1759, III, iii, 192) asks whether his representative European would be willing to "sacrifice the lives of a hundred millions of his brethren" to save the injury to his little finger. Smith concludes that the answer is "No": "Human nature startles with horror at the thought, and the world, in its greatest depravity and corruption, never produced such a villain as could be capable of entertaining it." The impartial spectator recognizes (194) that "we are but one of the multitude, in no respect better than any other in it.”

\section{Fairness}

Although Smith viewed altruism as a somewhat erratic force, he believed that other motivations played a more reliable civilizing role. Chief among these other 


\begin{tabular}{|l|l|l|l|l|l|l|}
\hline tapraid1/z30-jep/z30-jep/z3000305/z300587d05a & longd & S=5 & 6/30/05 & 11:53 & Art: & Input-yyy(psf) \\
\hline
\end{tabular}

\section{Journal of Economic Perspectives}

motivations was fairness. Smith (1759, II, ii, iii, 125) writes: "Nature has implanted in the human breast, that consciousness of ill-desert, those terrors of merited punishment which attend upon its violation, as the great safe-guards of the association of mankind, to protect the weak, to curb the violent, and to chastise the guilty." Smith believed this natural sentiment toward fairness was the source of the virtue of justice, which he saw as the "main pillar that upholds the whole edifice. If it is removed, the great, the immense fabric of human society . . must in a moment crumble to atoms." Moreover, Smith (129) viewed the desire for justice as something primal: "All men, even the most stupid and unthinking, abhor fraud, perfidy, and injustice, and delight to see them punished. But few men have reflected upon the necessity of justice to the existence of society, how obvious soever that necessity may appear to be."

Modern research suggests that an innate concern for fairness extends even beyond humans to other primates. Capuchin monkeys will reject small rewards when they see other monkeys they perceive as undeserving getting more than they do (Brosnan and de Waal, 2002). Cotton-top tamarins will pull a lever to give marshmallows (which tamarins love) to other tamirins who have altruistically rewarded them with marshmallows in earlier lever-pulls more often then they will pull levers to tamarins who were not previously altruistic (Hauser, Chen, Chen and Chang, 2003).

The impartial spectator plays an essential role in fairness, by causing individuals to internalize other people's sense of fairness by viewing their own actions through the eyes of an objective observer. Smith (1759, III, iii, 195) argues: "There is no commonly honest man who does not dread the inward disgrace of such an action."

\section{Altruism, Fairness and Market Interactions}

Market interactions require, as Boulding (1969, p. 5) points out, “a minimum degree of benevolence even in exchange without which it cannot be legitimated and cannot operate as a social organizer." Arrow (1974) also notes the importance of trust as a lubricant of exchange, economizing on the costs of gathering information about trading partners. For Adam Smith, a mixture of the concerns over fairness (enforced by the fear of negative appraisal by the impartial spectator) and altruism played an essential role in market interactions, allowing trust, repeated transactions and material gains to occur.

Smith described the beginnings of market exchange thus: "in a nation of hunters, if any one has a talent for making bows and arrows better than his neighbours he will at first make presents of them, and in return get presents of their game. By continuing this practice he will live better than before and will have no occasion to provide for himself, as the surplus of his own labor does it more effectually" (Smith, 1762-1763, 220).

As Jeffrey Young (1997, p. 62) remarks, "[T] he other regarding principles of human nature which bind people together in society are a necessary condition for the emergence of the exchange of surplus produce amongst neighbours. Smith 


\begin{tabular}{|l|l|l|l|l|l|l|}
\hline tapraid1/z30-jep/z30-jep/z3000305/z300587d05a & longd & $\mathrm{S}=5$ & $6 / 30 / 05$ & $11: 53$ & Art: & Input-yyy(psf) \\
\hline
\end{tabular}

uses the moral side of human nature to help him explain why voluntary agreement and not violence takes place when these two hunters meet."

In experiments, norms of positive reciprocity often create trust where it has no business flourishing (according to the textbook view that emphasizes moral hazard when contracts are incomplete)—among strangers in one-shot transactions. For example, in simple "trust game" experiments, subjects decide how much money to put in a mailbox, and their investment is tripled (representing a socially productive return). A second subject takes the tripled money out and can keep it all, or repay some to the original investor. Most experiments show that the second subject does repay money, even in one-shot games that control for anonymity, and they typically repay just enough to make the investment worthwhile (Berg, Dickhaut and McCabe, 1995; Camerer, 2003, chapter 2). Experiments run in Russia, South Africa and the United States showed that many trustors do not even expect to make money, but are motivated to "invest" by pure "warm-glow" altruism (Ashraf, Bohnet and Piankov, 2003). Simple models that incorporate a preference for fairness or equality have been developed and applied to a broad range of games (Rabin, 1993; in this journal, Fehr and Gächter, 2000).

Furthermore, trust, as measured in simple surveys, is strongly correlated with economic growth (Knack and Keefer, 1997) (though the direction of causality is unknown). An anthropology experiment involving 15 small-scale societies found that in societies in which people buy and sell more often in markets, offers in ultimatum bargaining games ${ }^{4}$ are, perhaps surprisingly, closer to equal sharing than in less market intensive societies (Henrich, Boyd, Bowles, Gintis, Fehr and Camerer, 2004). Adam Smith would not be surprised by the finding that markets are often built on motivations of fairness, altruism and trust-rather than on self-interest alone-yet this mixture of motivations remains a challenge to the modern economics profession.

\section{Consumption and Its Discontents}

In The Theory of Moral Sentiments, Smith argues that much economic activity is the product of a forecasting error-people's illusion that acquiring wealth, possessions and status will make them permanently happy. In fact, Smith (1759, III, iii, 209) argued, both pleasure and pain are often transient: "By the constitution of

\footnotetext{
${ }^{4}$ An "ultimatum game" has two players. The first player is given a sum of money. The player is instructed to offer some share of that money to the second player. If the second player accepts the division, then both players keep the money. If the second player rejects the division, both players receive zero. In a one-shot play of the game, if players are rational and self-interested, then the first player should offer the second player only a minimal amount, which the second player will accept because it is better than nothing. But when the game is actually played, small offers are commonly rejected (even for high stakes), and even in a one-shot game, it is common for the first player to offer a 50:50 split of the original stake. For expositions of the ultimatum game in this journal, see Thaler (1988) and Camerer and Thaler (1995).
} 


\begin{tabular}{|l|l|l|l|l|l|l|}
\hline tapraid1/z30-jep/z30-jep/z3000305/z300587d05a & longd & S=5 & 6/30/05 & 11:53 & Art: & Input-yyy(psf) \\
\hline
\end{tabular}

\section{Journal of Economic Perspectives}

human nature, agony can never be permanent." Following a calamity, he noted, a person "soon comes, without any effort, to enjoy his ordinary tranquility." Smith further observed that people not only adapt quickly to circumstances, but underestimate such adaptation and, as a result, often overestimate the duration of happy and sad feelings:

A man with a wooden leg suffers, no doubt, and foresees that he must continue to suffer during the remainder of his life, a very considerable inconveniency. He soon comes to view it, however, exactly as every impartial spectator views it; as an inconveniency under which he can enjoy all the ordinary pleasures both of solitude and of society .... He no longer weeps, he no longer laments, he no longer grieves over it, as a weak man may sometimes do in the beginning.

Considerable modern research backs up Smith's contentions. For example, Frederick and Loewenstein (1999) show the short-term impacts on happiness of both positive and negative outcomes. Indeed, Smith's example of the man with a wooden leg foreshadows a classic study by Brickman, Coates and Janoff-Bulman (1978) showing that the happiness of paraplegics and lottery winners tends to revert surprisingly close to a normal baseline after their respectively tragic and wonderful life-changing events. A large body of contemporary psychological research also suggests that people typically believe that pleasure and pain will last longer than they actually do (for example, Wilson and Gilbert, 2003).

At numerous points, Smith $(1759$, IV $, i, 259)$ expresses skepticism about the pleasure derived from possessions: "How many people ruin themselves by laying out money on trinkets of frivolous utility?" Smith further believed that the primary purpose of wealth-accumulation beyond a minimal level was not for consumption, but for the social attention. "What are the advantages which we propose by that great purpose of human life which we call bettering our condition?" Smith asked (I, iii, ii, 70-71). "To be observed, to be attended to, to be taken notice of with sympathy, complacency, and approbation, are all the advantages which we can propose to derive from it. It is the vanity, not the ease, or the pleasure, which interests us."

Smith devotes numerous pages of The Moral Sentiments to describing ways in which the anticipation of status gained was much better than the realization, since pursuit of status can backfire. Indeed, he argues (1759, IV, i, 260-261), even the wealthy and great eventually recognize, albeit long after they can remedy the situation, how little utility the goods they struggled so hard to procure have actually provided:

Through the whole of his life he pursues the idea of a certain artificial and elegant repose which he may never arrive at, for which he sacrifices a real tranquility that is at all times in his power, and which, if in the extremity of old age he should at last attain to it, he will find to be in no respect preferable to 


\begin{tabular}{|l|l|l|l|l|l|l|}
\hline tapraid1/z30-jep/z30-jep/z3000305/z300587d05a & longd & $\mathrm{S}=5$ & $6 / 30 / 05$ & $11: 53$ & Art: & Input-yyy(psf) \\
\hline
\end{tabular}

that humble security and contentment which he had abandoned for it. It is then, in the last dregs of life, his body wasted with toil and disease, his mind galled and ruffled by the memory of a thousand injuries and disappointments which he imagines he has met with from the injustice of his enemies, or from the perfidy and ingratitude of his friends, that he begins at last to find that wealth and greatness are mere trinkets of frivolous utility, no more adapted for procuring ease of body or tranquility of mind, than the tweezer-cases of the lover of toys.

Smith would have done well to heed his own advice. He worked himself so sick in drafting The Wealth of Nations that in 1773, he sent David Hume a letter making Hume his literary executor in case he should die before publishing any of his manuscripts (though as it turned out, Smith outlived Hume by 14 years).

Because the rich pursue ends that fail to make them happy, Smith (1759, IV, $i, 265$ ) believed that they end up being no more happy than the poor: "In ease of body and peace of mind, all the different ranks of life are really upon a level, and the beggar, who suns himself by the side of the highway, possesses that security which kings are fighting for" and "in what constitutes the real happiness of human life, [the poor] are in no respect inferior to those who would seem so much above them." Indeed, a large body of modern research on the determinants of happiness has quite consistently found surprisingly weak connections between happiness and wealth or income, especially over time or across countries (Easterlin, 1974; Diener, and Biswas-Diener, 2002; Frey and Stutzer, 2002).

Yet while believing that consumption of goods, as well as wealth and greatness, all provide only "frivolous utility," Smith believed that the productivity of market economy is driven by this "deception"-the misguided belief that wealth brings happiness. As Smith (1759, IV, $i, 263-264)$ notes, "[I]t is this deception which rouses and keeps in continual motion the industry of mankind. It is this which first prompted them to cultivate the ground, to build houses, to found cities and commonwealths, and to invent and improve all the sciences and arts, which ennoble and embellish human life; which have entirely changed the whole face of the globe."

Indeed, Adam Smith even invokes the "invisible hand"-a term that may be the the most prominent legacy of his work, although it occurs only once in The Wealth of Nations and only once in The Theory of Moral Sentiments-to argue that as the wealthy seek out goods and status that ultimately bring them little pleasure, they inadvertently end up promoting the good of the poor. ${ }^{5}$ Here is Smith's invisible hand $(1759, \mathrm{IV}, i, 264)$ in The Theory of Moral Sentiments:

\footnotetext{
${ }^{5}$ For discussion in this journal of the context for the "invisible hand" in The Wealth of Nations, see Persky (1989). For a discussion in this journal of the "invisible hand" in the context of The Theory of Moral Sentiments and Adam Smith's ethical system, see Evensky (1993).
} 


\begin{tabular}{|l|l|l|l|l|l|l|}
\hline tapraid1/z30-jep/z30-jep/z3000305/z300587d05a & longd & S=5 & 6/30/05 & 11:53 & Art: & Input-yyy(psf) \\
\hline
\end{tabular}

\section{Journal of Economic Perspectives}

"In spite of their natural selfishness and rapacity, though they mean only their own conveniency, though the sole end which they propose from the labours of all the thousands whom they employ be the gratification of their own vain and insatiable desires, they divide with the poor the produce of all their improvements. They are led by an invisible hand to make nearly the same distribution of the necessities of life which would have been made had the earth been divided into equal portions among all inhabitants; and thus, without intending it, without knowing it, advance the interest of the society."

While perhaps overstating the case, when Smith refers to the equitable distribution of the necessities of life he is arguing that the distribution of things that actually bring happiness to people is far more equitable than the distribution of tweezercases and other "trinkets of frivolous utility." That the things that really matter for happiness are more equitably distributed than those that don't may help to explain why cross-sectional differences in income seem to bring such small increments in happiness.

\section{Unexploited Ideas}

Adam Smith's Theory of Moral Sentiments is not only packed with insights that presage developments in contemporary behavioral economics, but also with promising leads that have yet to be pursued. Here we enumerate four of them: the desire to be well-regarded by posterity; negative reactions to being misjudged; mistaken belief in the objectivity of tastes; and sympathy for the great and rich.

A desire to be well-regarded by posterity certainly drives the efforts of many creative professionals_-artists, writers, architects and academic economists. As Smith (1759, I, ii, 169) comments, "Men have voluntarily thrown away life to acquire after death a renown which they could no longer enjoy. Their imagination, in the meantime, anticipated that fame which was in future times to be bestowed upon them." A concern for one's reputation to posterity might be thought of as reserved for the richest and most powerful members of society, many of who do seem to care about it based on the named buildings in universities and hospitals, but it is not limited to the rich. Economists have studied the bequest motive, which is no doubt partly fueled by this motive, but they have not yet explored what may be more potent effects of posterity on current decisions-perhaps starting with the decision to have children or to encourage grandchildren.

Economics generally assumes that people care about outcomes, not about the source of outcomes. However, Adam Smith pointed out that people have negative reactions to being misjudged that go beyond the outcome. Smith (1759, III, ii, 174) drew special attention to one particular situation-that of "unmerited reproach," which, he noted, "is frequently capable of mortifying very severely even men of more than ordinary constancy .... An innocent man, brought to the scaffold by the false imputation of an infamous or odious crime, suffers the most cruel 


\begin{tabular}{|l|l|l|l|l|l|l|}
\hline tapraid1/z30-jep/z30-jep/z3000305/z300587d05a & longd & $\mathrm{S}=5$ & $6 / 30 / 05$ & $11: 53$ & Art: & Input-yyy(psf) \\
\hline
\end{tabular}

misfortune which it is possible for innocence to suffer." Resesarch on "procedural justice" shows a substantial concern for whether a trial was fair, for example, as well as for the outcome of the trial (Lind and Tyler, 1988). One study showed that the propensity to file wrongful-termination lawsuits after firing is correlated with workers' perceptions of whether their firing was just (controlling for expected payoffs from litigation; Lind, Greenberg, Scott and Welchans, 2000). This insight has interesting implications for principal-agent theory. Smith's insights suggest that goodwill could be seriously eroded if a principal penalizes an agent who produced a low level of output due to bad luck rather than poor effort.

Ample evidence-beginning with the huge cross-cultural differences in tastes for food-suggests that tastes are subjective, based on a culture, familiarity and so on. However, Smith argued that people underestimate such influences, having instead a mistaken belief in objectivity of tastes. Smith $(1759, \mathrm{~V}, i)$ commented, "[F]ew men ... are willing to allow, that custom or fashion have much influence upon their judgments concerning what is beautiful, . . . imagine that all the rules which they think ought to be observed in each of them are founded upon reason and nature, not upon habit or prejudice." Ross and Ward (1996) refer to the tendency for people to think their own tastes and beliefs are more legitimate and more widely shared than they really are as naïve realism. Naïve realism has potentially important implications for a variety of economic issues: gift-giving; negotiations in which both parties are likely to think that their own preferences are shared by the other side more than they are; principal-agent situations in which the principal has to set rewards for the agent; and sales and marketing (Davis, Hoch and Ragsdale, 1986). It can also lead to cultural conflict. If those in one society believe that eating monkey is inherently disgusting, then we are likely to disparage monkey-eaters, rather than treating the tastes of those who disagree as akin to tastes for opera or smelly cheese.

Finally, contrary to the sensible notion that one should sympathize with those less fortunate than oneself, Smith (1759, iii, $i i, 72-73)$ argued that there is a natural tendency to experience sympathy for the great and rich:

When we consider the condition of the great, in those delusive colours in which the imagination is apt to paint it, it seems to be almost the abstract idea of a perfect and happy state. It is the very state which, in all our waking dreams and idle reveries, we had sketched out to ourselves as the final object of all our desires. We feel, therefore, a peculiar sympathy with the satisfaction of those who are in it. We favour all their inclinations, and forward all their wishes. What pity, we think, that any thing should spoil and corrupt so agreeable a situation! It is the misfortunes of kings only which afford the proper subjects for tragedy.

Smith's description recalls the outpouring of grief after the accidental deaths of Princess Diana and John F. Kennedy Jr. Popular Magazines like People and US, and similar highly rated TV shows, are filled with stories about where athletes and stars 


\begin{tabular}{|l|l|l|l|l|l|l|}
\hline tapraid1/z30-jep/z30-jep/z3000305/z300587d05a & longd & $\mathrm{S}=5$ & $6 / 30 / 05$ & $11: 53$ & Art: & Input-yyy(psf)
\end{tabular}

\section{Journal of Economic Perspectives}

shop, what they eat and wear and the ups and downs of their love lives. Fascination with celebrity of this sort also has a direct economic effect through the use of celebrities as marketing vehicles.

Smith believed both that this sympathy for the rich was a form of corruption based on a moral mistake, and also that it provided an important underpinning for social stability. Smith (1759, I, iii, iii, 84) described the moral mistake in this way: "[T] hat wealth and greatness are often regarded with the respect and admiration which are due only to wisdom and virtue; and that the contempt, of which vice and folly are the only proper objects, is most unjustly bestowed upon poverty and weaknesses, has been the complaint of moralists in all ages." Indeed, Smith further argued that the "disposition to admire, and almost to worship, the rich and the powerful, and to despise, or at least, to neglect, persons of poor and mean condition ... is ... the great and most universal cause of the corruption of our moral sentiments." However, Smith (I, iii, iii) also held that this sympathy was "necessary both to establish and to maintain the distinction of ranks and the order of society." This sympathy for the rich may help to explain one of the puzzles of capitalism: the failure of the majority democratic societies to impose extremely high taxes on the richest members. Smith's perspective suggests that maybe people don't want to tax the rich because average citizens don't want to "spoil and corrupt" what they perceive as the "agreeable situation" of the rich!

\section{Conclusion}

Adam Smith's actors in The Theory of Moral Sentiments are driven by an internal struggle between their impulsive, fickle and indispensable passions, and their impartial spectator. They weigh out-of-pocket costs more than opportunity costs, have self-control problems and are overconfident. They display erratic patterns of sympathy, but are consistently concerned about fairness and justice. They are motivated more by ego than by any kind of direct pleasure from consumption, and, though they don't anticipate it, ultimately derive little pleasure from either. In short, Adam Smith's world is not inhabited by dispassionate rational purely selfinterested agents, but rather by multidimensional and realistic human beings.

- Thanks to Kim Border for an apt Adam Smith quotation; to Eric Angner, James Hines, Jesse Shapiro, Jeremy Tobacman, Timothy Taylor and Michael Waldman for helpful comments; and to Ed Glaeser and Andrei Shleifer for encouragement. 


\begin{tabular}{|l|l|l|l|l|l|l|}
\hline tapraid1/z30-jep/z30-jep/z3000305/z300587d05a & longd & $\mathrm{S}=5$ & $6 / 30 / 05$ & $11: 53$ & Art: & Input-yyy(psf) \\
\hline
\end{tabular}

\section{References}

Angeletos, George-Marios, David Laibson, Jeremy Tobacman, Andrea Repetto and Stephen Weinberg. 2001. "The Hyperbolic Consumption Model: Calibration, Simulation, and Empirical Evaluation." Journal of Economic Perspective. 15:3, pp. $47-68$.

Arrow, Kenneth. 1974. The Limits of Organisation. New York: Norton.

Ashraf, Nava, Dean Karlan and Wesley Yin. 2004. "Tying Odysseus to the Mast: Evidence from a Commitment Savings Product in the Philippines." Mimeo.

Ashraf, Nava, Iris Bohnet and Nikita Piankov. 2003. "Is Trust a Bad Investment?" Kennedy School of Government Working Paper No. 03047, November.

Bénabou, Roland and Marek Pyciak. 2002. "Dynamic Inconsistency and Self-Control: A Planner-Doer Interpretation." Economics Letters. 77:3, pp. 419-24.

Benartzi Shlomo and Richard Thaler. 1997. "Myopic Loss Aversion and the Equity Premium Puzzle." Quarterly Journal of Economics. 110:1, pp. 73-92.

Benhabib, Jess and Alberto Bisin. 2002. "SelfControl and Consumption-Savings Decisions: Cognitive Perspectives." New York University.

Berg, Joyce, John Dickhaut and Kevin A. McCabe. 1995. "Trust, Reciprocity, and Social History." Games and Economic Behavior. 10:1, pp. 290-307.

Bernheim, Douglas and Antonio Rangel. 2004. "Addiction and Cue-Triggered Decision Processes." American Economic Review. 94:5, pp. $1558-590$

Bohnet, Iris and Bruno Frey. 1999. "The Sound of Silence in Prisoner's Dilemma and Dictator Games." Journal of Economic Behavior and Organization. 38:1, pp. 43-57.

Boulding, Kenneth E. 1969. "Economics as a Moral Science." American Economic Review. 59:1, pp. 1-12.

Brickman, Philip, Dan Coates and Ronnie Janoff-Bulman. 1978. "Lottery Winners and Accident Victims: Is Happiness Relative?” Journal of Personality and Social Psychology. 36:8, pp. 917-27.

Brosnan, Sarah F. and Frans B. M. de Waal. 2002. "A Proximate Perspective on Reciprocal Altruism.” Human Nature. 13:1, pp. 129-52.

Camerer, Colin F. 2003. Behavioral Game Theory: Experiments on Strategic Interaction. Princeton: Princeton University Press.

Camerer, Colin and Dan Lovallo. 1999. "Overconfidence and Excess Entry: An Experimental
Approach.” American Economic Review. 89:1, pp. 306-18.

Camerer, Colin F. and George Loewenstein. 2004. "Behavioral Economics: Past, Present, Future," in Advances in Behavioral Economics. Colin F. Camerer, George Loewenstein and Mathew Rabin, eds. New York: Russell Sage, pp. 3-51.

Camerer, Colin F., Linda Babcock, George Loewenstein and Richard Thaler. 1997. "Labor Supply of New York City Cab Drivers: One Day at a Time." Quarterly Journal of Economics. May, 111, pp. 408-41.

Camerer, Colin and Richard Thaler. 1995. "More Dictator and Ultimatum Games." Journal of Economic Perspectives. 9:2, pp. 209-19.

Damasio, Antonio R. 1994. Descartes' Error: Emotion, Reason, and the Human Brain. New York: Putnam.

Davis, Harry L., Steven J. Hoch and E. K. Easton Ragsdale. 1986. "An Anchoring and Adjustment Model of Spousal Predictions.” Journal of Consumer Research. 13:1, pp. 25-37.

Diener, Edward and R. Biswas-Diener. 2002. "Will Money Increase Subjective Well-Being?" Social Indicators Research. 57:2, pp. 119-69.

Easterlin, Richard. 1974. "Does Economic Growth Improve the Human Lot?" in Nations and Households in Economic Growth: Essays in Honor of Moses Abramovitz. Paul A. David and Melvin W. Reder, eds. New York: Academic Press, pp. 89-125.

Eckel, Catherine and Philip Grossman. 1996. "Altruism in Anonymous Dictator Games." Games and Economic Behavior. 16:2, pp. 181-91.

Evensky, Jerry. 1993. "Retrospectives: Ethics and the Invisible Hand." Spring, 7:2, pp. 197205.

Fehr, Ernst and Simon Gächter. 2000. "Fairness and Retaliation: The Economics of Reciprocity." Journal of Economic Perspectives. 14:3, pp. 159-81.

Frey, Bruno and Alois Stutzer. 2002. "What Can Economists Learn from Happiness Research?" Journal of Economic Literature. 40:2, pp. 402-35.

Fudenberg, Drew and David Levine. 2004. "A Dual Self Model of Impulse Control." Working paper, February.

Genesove, David and Christopher Mayer. 2001. "Loss Aversion and Seller Behavior: Evidence from the Housing Market. Quarterly Journal of Economics. 116:4, pp. 1233-260.

Grampp, William. 1948. "Adam Smith and the 


\section{Journal of Economic Perspectives}

Economic Man.” Journal of Political Economy. 56:4, pp. 315-36.

Heifetz, A. and Yossi Spiegel. 2000. "On the Evolutionary Emergence of Optimism.” Discussion Paper No. 1304, Northwestern University, Center for Mathematical Studies in Economics and Management Science.

Henrich, Joseph, Robert Boyd, Samuel Bowles, Herbert Gintis, Ernst Fehr and Colin Camerer. 2004. Foundations of Human Sociality: Ethnography and Experiments in 15 Small-Scale Societies. Oxford University Press.

Hauser, Marc D., M. Keith Chen, Frances Chen and Emmeline Chang. 2003. "Give Unto Others: Genetically Unrelated Cotton-top Tamarin Monkeys Preferentially Give Food to Those Who Altruistically Give Food Back." Proceedings of the Royal Society B. 270, pp. 2363-370.

Kahneman, Daniel and Amos Tversky. 1979. "Prospect Theory: An Analysis of Decision Under Risk." Econometrica. 47:2, pp. 263-91.

Knack, Stephen and Philip Keefer. 1997. "Does Social Capital Have an Economic Payoff? A Cross-Country Investigation." Quarterly Journal of Economics. 112:4, pp. 1251-288.

Kahneman, Daniel, Jack L. Knetsch and Richard Thaler. 1990. "Experimental Tests of the Endowment Effect and the Coase Theorem. Journal of Political Economy. 98:6, pp. 1325-348.

Kirkpatrick, Lee A. and Seymour Epstein. 1992. "Cognitive-Experiential Self-Theory and Subjective Probability: Further Evidence for Two Conceptual Systems." Journal of Personality and Social Psychology. 63:4, pp. 534-44.

Laibson, David. 1997. "Golden Eggs and Hyperbolic Discounting." Quarterly Journal of Economics. 112:2, pp. 443-77.

LeDoux, Joseph E. 1996. TheEemotional Brain: The Mysterious Underpinnings of Emotional Life. New York, N.Y.: Simon \& Schuster.

Lind, E. Allen, Jerald Greenberg, Kimberly Scott and Thomas Welchans. 2000. "The Winding Road from Employee to Complainant: Situational and Psychological Determinants of Wrongful-Termination Claims." Administrative Science Quarterly. 45:3, pp. 557-90.

Lind, E. Allen and Thomas R. Tyler. 1988. The Social Psychology of Procedural Justice. New York: Plenum Press.

Frederick, Shane and George Loewenstein. 1999. "Hedonic Adaptation," in Well-Being: The Foundations of Hedonic Psychology. Daniel Kahneman, Edward Diener and Norbert Schwarz, eds. New York: Russell Sage Foundation Press, pp. 302-29.

Loewenstein, George and Ted O'Donoghue. 2004. "Animal Spirits: Affective and Deliberative
Influences on Economic Behavior." Working paper, Department of Social and Decision Sciences, Carnegie Mellon University; Available at 〈http://papers.ssrn.com/sol3/papers.cfm?abstract _id $=539843\rangle$.

Metcalf, Janet and Walter Mischel. 1999. "A Hot/Cool-System Analysis of Delay of Gratification: Dynamics of Willpower." Psychological Review. 106:1, pp. 3-19.

McClure, Sam, David Laibson, George Loewenstein and Jonathan Cohen. 2004. "Separate Neural Systems Value Immediate and Delayed Monetary Rewards.” Science. 304:5695, pp. 50307.

Odean, Terrance. 1998. "Are Investors Reluctant to Realize their Losses?” Journal of Finance. 53:5, pp. 1775-798.

O'Doherty J., M. L. Kringelbach, E. T. Rolls, J. Hornak and C. Andrews. 2001. "Abstract Reward and Punishment Representations in the Human Orbitofrontal Cortex." Nature Neuroscience. 4:1, pp. 95-102.

O'Donoghue, Ted and Matthew Rabin. 1999. "Doing It Now or Doing It Later." American Economic Review. 89:1, pp. 103-21.

Panksepp, Jaak. 1998. Affective Neuroscience. Oxford: Oxford University Press.

Persky, Joseph. 1989. "Retrospectives: Adam Smith's Invisible Hands." Journal of Economic Perspectives. Fall, 3:4, pp. 195-201.

Postlewaite, Andrew and Olivier Compte. 2001. “Confidence Enhanced Performance.” Working paper, University of Pennsylvania; Available at 〈http://www.ssc.upenn.edu/\% 7Eapostlew/paper/ working.html .

Rabin, Matthew. 1993. "Incorporating Fairness into Game Theory and Economics." American Economic Review. 83:5, pp. 1281-302.

Roll, Richard. 1986. "The Hubris Hypothesis of Corporate Takeovers." Journal of Business. 59:2, pp. 197-216.

Ross, Lee and Andrew Ward. 1996. "Naive Realism in Everyday Life: Implications for Social Conflict and Misunderstanding," in Values and Knowledge. T. Brown, E. Reed and E. Turiel, eds. Mahwah, N.J.: Lawrence Erlbaum Associates, Inc., pp. 103-36.

Shefrin, Hersh M. and Richard H. Thaler. 1981. "An Economic Theory of Self-Control." Journal of Political Economy. April, 89:2, pp. 392406.

Sloman, Steven A. 1996. "The Empirical Case for Two Systems of Reasoning." Psychological Bulletin. 119:1, pp. 3-22.

Small, Deborah A. and George Loewenstein. 2003. "Helping $a$ Victim or Helping the Victim: 
Altruism and Identifiability." Journal of Risk and Uncertainty. 26:1, pp. 5-16.

Smith, Adam. 1776 [1981]. An Inquiry into the Nature and Causes of the Wealth of Nations, Volumes I and II. R. H. Campbell and A. S. Skinner, eds. Liberty Fund: Indianopolis.

Smith, Adam. 1762-1763 [1976a]. Lectures on Jurisprudence. R. L. Meek, D. D. Raphael and A. L. Macfie, eds. Oxford: Clarendon Press.

Smith, Adam. 1759 [1981]. The Theory of Moral Sentiments. D. D. Raphael and A. L. Macfie, eds. Liberty Fund: Indianapolis.

Smith, Vernon L. 1998. "The Two Faces of Adam Smith." Southern Economic Journal. 65:1, pp. 2-19.

Taylor, Shelly E. and Jonathon D. Brown. 1994. "Positive Illusions and Well-Being Revisited: Separating Fact from Fiction." Psychological Bulletin. 116, pp. 21-27.

Tengs, Tammy O. and John D. Graham. 1996.
"The Opportunity Costs of Haphazard Social Investments in Life-Saving," in Risks, Costs and Lives Saved. Robert W. Hahn, ed. New York: Oxford University Press, pp. 167-79.

Thaler, Richard. 1988. "The Ultimatum Game.” Journal of Economic Perspectives. Fall, 2:4, pp. 195-206.

Thaler, Richard. 1980. "Toward a Positive Theory of Consumer Choice." Journal of Economic Behavior and Organization. 1:1, pp. 39-60.

Waldman, Michael. 1994. "Systematic Errors and the Theory of Natural Selection." American Economic Review. 84:3, pp. 482-97.

Wilson, Timothy D. and Daniel T. Gilbert. 2003. "Affective Forecasting," in Advances in Experimental Social Psychology. Mark Zanna, ed. New York: Elsevier, pp. 345-411.

Young, Jeffrey T. 1997. Economics as a Moral Science: The Political Economy of Adam Smith. Cheltenham: Edward Elgar. 